\title{
MANAJEMEN PENDIDIKAN KHUSUS ANAK TUNAGRAHITA SEKOLAH LUAR BIASA NEGERI OGAN ILIR SUMATERA SELATAN
}

\author{
Fajri $^{1}$, Waspodo ${ }^{2}$ \\ Mahasiswa Universitas Bina Darma ${ }^{1}$, Dosen Universitas Bina Darma ${ }^{2}$ \\ Jalan Jenderal Ahmad Yani No. 3 Palembang \\ Sur-el: fajri269082@gmail.com¹,waspodo@binadarma.ac.id ${ }^{2}$
}

Article info

Article history:

Received:28-08-2021

Revised :12-09-2021

Accepted:16-12-2021
Keywords:

Education

Management,

Special Education,

Children with

Mental

Requirenments

Kata Kunci:

Manajemen

Pendidikan, Sekolah

Luar Biasa, dan Anak

Tunagrahita

\begin{abstract}
A B S T R A C T
This study used descriptive qualitative method. Data collection was done by interview, observation, and documentation. Data analysis techniques were carried out through data reduction, data presentation, and drawing conclusions. The results show that the success of educational management applied to mentally retarded children cannot be separated from the existence of a good management process, namely from the planning process, organizing process, implementation process, and control process. The supporting factors for implementing such management include local government support, an adequate organizational structure, and the ability of teachers and parental support. While the inhibiting factors from the application of such management are the condition of mentally retarded students who have different characteristics, the location of the school is far from public roads, and the entry of students with different disabilities from other mentally retarded students.
\end{abstract}

Penelitian ini menggunakan metode deskriptif kualitatif. Pengumpulan data dilakukan dengan wawancara, observasi, dan dokumentasi. Teknik analisis data dilakukan melalui reduksi data, penyajian data, dan penarikan kesimpulan. Hasil menunjukkan bahwa keberhasilan manajemen pendidikan yang diterapkan pada anak tunagrahita tidak terlepas dari adanya proses pengelolaan yang baik yaitu dari proses perencanaan, proses pengorganisasian, proses pelaksanaan, serta proses pengendalian. Adapun faktor pendukung dari penerapan manajemen tersebut seperti adanya dukungan pemerintah daerah, struktur organisasi yang memadai, serta adanya kemampuan guru dan dukungan orang tua. Sedangkan faktor penghambat dari penerapan manaejemen tersebut seperti kondisi siswa tunagrahita yang memiliki karakteristik yang berbeda-beda, letak sekolah yang jauh dari jalan umum, dan masuknya siswa dengan kondisi ketunaan yang berbeda dengan siswa tunagrahita lainnya. 


\section{PENDAHULUAN}

Permendiknas Nomor 70 Tahun 2009 tentang pendidikan inklusi menyatakan bahwa mewajibkan setiap daerah dapat menyelenggarakan pendidikan inklusi. Direktorat PSLB (2007), mengatakan bahwa sekolah inklusi harus melalui seleksi dan memiliki kesiapan manajemen. Sekolah Luar Biasa Negeri Kabupaten Ogan Ilir adalah lembaga pendidikan khusus negeri satu-satunya yang berada di bawah naungan Kementerian Pendidikan dan Kebudayaan Kabupaten Ogan Ilir Provinsi Sumatera Selatan. Kehadiran Sekolah Luar Biasa ini dalam proses pendidikannya sangat dibutuhkan oleh para orang tua, khususnya yang berada di wilayah tersebut yang mengiginkan pendidikan terus berjalan meskipun anak-anak mereka memiliki keterbatasan dan kelainan khusus atau keterbelakangan mental (tunagrahita). SLB ini berada di Jalan Pasirah Matnang Desa Tanjung Pering Kecamatan Indralaya Utara, Kabupaten Ogan Ilir Sumatera Selatan yang telah ada sejak tanggal 24 April 2009, berdasarkan izin operasional Nomor: 420/089/DS.3/D.Dik-OI/2009 yang diterbitkan oleh Kepala Dinas Pendidikan Kabupaten Ogan Ilir.

Dalam menjalankan proses pendidikannya, SLB Negeri Ogan Ilir mempunyai visi, misi serta tujuan yang ingin dicapai. Untuk dapat mewujudkan visi, misi dan tujuan dari SLB Negeri Ogan Ilir seperti yang telah diuraikan sebelumnya, maka diperlukan suatu manajemen khususnya manajeman pendidikan yang baik dalam merumuskan dan mengelola program kerja lembaga dalam hal ini adalah SLB Negeri Ogan Ilir. Hal yang sama seperti disampaikan oleh Noordyana (2016), "bahwa perkembangan zaman selalu memunculkan persoalan-persoalan baru yang tidak pernah terpikirkan sebelumnya".

Berdasarkan permasalahan sebelumnya, permasalahan pendidikan masih mengalami kurang mendapat perhatian dari pemerintah. Ada pun hal tersebut dapat dilihat dari semakin beragamnya permasalahan pendidikan yang semakin rumit seperti yang diungkapkan oleh Widodo, dkk (2011). Dari berbagai permasalahan yang telah diuraikan tersebut, hal ini disebabkan oleh rendahnya alokasi dari rata-rata anggaran pendidikan mulai dari tingkat nasional, provinsi, kabupaten/kota seperti yang dikatakan oleh Mantja (2016). Beranjak dari permasalahan yang ada, maka diperlukan suatu rancangan sistem pendidikan yang dianggap dapat menciptakan suasana agar proses pembelajaran yang dilakukan dapat terasa menyenangkan, memberikan rangsangan serta dapat membangkitkan semangat siswa agar dapat mengembangkan potensi dirinya secara maksimal yang disesuaikan dengan bakat dan kemampuannya (Mailani, 2018). 


\section{JURNAL ILMIAH \\ BINA EDUKASI \\ ISSN 1979-8598 E-ISSN: 2655-8378 \\ http://journal.binadarma.ac.id/index.php/jurnalbinaedukasi \\ Vol. 14, No. 2, Desember 2021, 142 - 156}

Penelitian ini khusus membahas pada anak yang mengalami ketunaan jenis tunagrahita. Menurut Mapunarti (2007), mengatakan bahwa "dari sudut bahasa atau istilah tunagrahita berasal dari kata "Tuna" dan "Grahita" tuna artinya cacat dan grahita artinya berfikir. Tunagrahita juga mempunyai arti kelainan yang meliputi fungsi intelektual umum di bawah rata-rata yaitu IQ 84 kebawah berdasarkan tes dan muncul sebelum usia 16 tahun. Dalam masyarakat tunagrahita sering disebut dengan istilah lemah pikiran, berkebelakangan mental, bodoh, cacat mental, ketergantungan penuh".

Berdasarkan pengamatan awal yang dilakukan di SLB Negeri Ogan Ilir seperti yang telah diuraikan di atas, ada beberapa hal yang menjadi permasalahan seperti pada sarana dan prasarana, seharusnya tersedia sarana/prasarana untuk menunjang keterampilan peserta didik, selain itu juga kurang tersedianya sumber daya manusia (SDM) pada guru-guru terutama pada saat menyiapkan komponen pembelajaran seperti silabus dan RPP pada saat akan memulai kegiatan belajar mengajar, kurangnya perhatian dari pemerintah terhadap pengembangan profesi dan keterampilan guru SLB seperti dengan cara mengadakan pelatihan ataupun workshop menjadi hal yang sangat penting. Selain itu juga pada sistem penerimaan peserta didik baru pada SLB Negeri Ogan Ilir belum dilakukan dengan cara sebagai mana mestinya, seperti adanya surat keterangan Test IQ peserta didik, surat keterangan psikolog ataupun surat keterangan kesehatan dari dokter THT.

Berdasarkan uraian sebelumnya, maka alasan peneliti melakukan penelitian di SLB Negeri Ogan Ilir adalah bahwa SLB ini adalah satu-satunya SLB yang ada di Kabupaten Ogan Ilir, selain itu keberadaan sekolah ini sangat membantu masyarakat yang memandang penting akan pendidikan bagi putra putrinya yang berkebutuhan khusus terutama yang menyandang tunagrahita. Beranjak dari uraian yang telah dijelaskan pada latar belakang, maka tujuan dari penelitian ini adalah untuk mengetahui: Bagaimana penerapan manajemen pendidikan khusus anak tunagrahita Sekolah Luar Biasa Negeri Ogan Ilir Sumatera Selatan?

\section{METODOLOGI PENELITIAN}

\subsection{Hakikat Pendidikan}

Munib (2004) mengatakan bahwa pendidikan memiliki hakikat yaitu "sebagai usaha sadar dan terencana dalam rangka mewujudkan suasana belajar dan proses pembelajaran agar peserta didik secara aktif mengembangkan potensi dirinya untuk memiliki potensi spiritual 


\section{JURNAL ILMIAH \\ BINA EDUKASI \\ ISSN 1979-8598 E-ISSN: 2655-8378 \\ http://journal.binadarma.ac.id/index.php/jurnalbinaedukasi \\ Vol. 14, No. 2, Desember 2021, 142 - 156}

keagamaan, pengendalian diri, kepribadian, kecerdasan, akhlak mulia, serta keterampilan yang diperlukan dirinya, masyarakat, bangsa dan negara".

Pendidikan jelaslah sangat berperan penting dalam kehidupan manusia dalam bermasyarakat, berbangsa dan bernegara. Taufiq, dkk (2011) mengatakan bahwa "pendidikan setidak-tidaknya memiliki ciri sebagai berikut: (1) pendidikan merupakan proses mengembangkan kemampuan, sikap, dan bentuk-bentuk tingkah laku lainnya di dalam masyarakat, dimana dia hidup; (2) pendidikan merupakan proses sosial, dimana seseorang dihadapkan pada pengaruh lingkungan yang terpilih dan terkontrol (khususnya yang datang dari sekolah) untuk mencapai kompetensi sosial dan pertumbuhan individual secara optimum; dan (3) pendidikan merupakan proses pengembangan pribadi atau watak manusia".

Berdasarkan pendapat ahli di atas dapat disimpulkan bahwa pendidikan terdiri dari pengajaran pada keahlian khusus, proses belajar mengajar adalah sesuatu yang tidak dapat dilihat akan tetapi dapat lebih mendalam yaitu tentang bagaimana pemberian pengetahuan, pertimbangan dan kebijaksanaan. Seperti yang kita ketahui bahwa pendidikan memiliki dasar utamanya yaitu untuk memberikan pengajaran kebudayaan kepada setiap generasi selanjutnya. Hal ini dapat terlihat pada berhasil atau tidaknya sistem pendidikan tersebut jika dapat berguna dan berdaya guna jika semunya itu berakar mendalam pada nilai- nilai yang ada dalam pandangan hidup suatu bangsa.

\subsubsection{Manajemen Pendidikan}

\subsubsection{Pengertian Manajemen Pendidikan}

Arikunto (2008) mengatakan bahwa "manajemen pendidikan adalah suatu kegiatan atau rangkaian kegiatan yang berupa proses pengelolaan usaha kerjasama sekelompok manusia yang tergabung dalam organisasi pendidikan, untuk mencapai tujuan yang telah ditetapkan sebelumnya, agar efektif dan efisien". Lebih lanjut dikatakan oleh Arikunto bahwa "yang dikelola dalam manajemen adalah semua bentuk kegiatan yang dikelompokkan dalam komponen-komponen. Adapaun komponen- komponen manajemen pendidikan meliputi: (1) manajemen kesiswaan; (2) manajemen personil; (3) manajemen kurikulum; (4) manajemen sarana; (5) manajemen pembiayaan: (6) manajemen lembaga-lembaga pendidikan dan terakhir; (7) manajemen hubungan masyarakat", (Arikunto, 2008).

Manajemen pendidikan merupakan suatu proses dari perencanaan, penorganisasian, pengarahan, pengawasan, dan penilaian usaha-usaha pendidikan agar bisa mencapai tujuan pendidikan yang sudah di tetapkan sebelumnya, (Bitar, 2020). Hamalik (2007) mengatakan bahwa "manajemen pendidikan adalah menyatukan beberapa unsur dalam pendidikan dan 


\section{JURNAL ILMIAH}

BINA EDUKASI

ISSN 1979-8598 E-ISSN: 2655-8378

http://journal.binadarma.ac.id/index.php/jurnalbinaedukasi

Vol. 14, No. 2, Desember 2021, 142 - 156

kemudian mencoba untuk dikembangkan dan fokus untuk mencapai pada tujuan dari manajemen pendidikan itu sendiri”.

Berdasarkan pengertian manajemen pendidikan di atas, dapat disimpulkan bahwa "manajemen pendidikan adalah suatu proses atau sistem pengelolaan manajemen pendidikan sebagai suatu proses atau sistem organisasi dan peningkatan kemanusiaan dalam kaitannya dengan suatu sistem pendidikan".

\subsubsection{Tujuan Manajemen Pendidikan}

Berikut adalah tujuan manajemen pendidikan menurut Bitar (2020):

1. Produktivitas, adalah perbandingan terbaik antara hasil yang diperoleh (output) dengan jumlah sumber yang dipergunakan (input). Produktivitas dapat dinyatakan secara kuantitas maupun kualitas ;

2. Kualitas, menunjukkan kepada suatu ukuran penilaian atau penghargaan yang diberikan atau dikenakan kepada barang (products) dan/atau jasa (services) tertentu berdasarkan pertimbangan objektif atas bobot dan/atau kinerjanya;

3. Efektivitas, adalah ukuran keberhasilan tujuan organisasi;

4. Efesiensi, berkaitan dengan cara yaitu membuat sesuatu dengan betul (doing things right) sementara efektivitas adalah menyangkut tujuan (doing the right things) atau efektivitas adalah perbandingan antara rencana tujuan yang dicapai. Efesiensi lebih ditekankan pada perbandingan antara input/sumber daya dengan output. Efesiensi pendidikan adalah bagaimana tujuan itu dicapai dengan memiliki tingkat efesiensi waktu, biaya, tenaga dan sarana.

\subsubsection{Prinsip Manajemen Pendidikan}

Bitar (2020), mengatakan bahwa prinsip-prinsip manajemen pendidikan dapat dirumuskan sebagai berikut.

1. memprioritaskan tujuan di atas kepentingan pribadi dan kepentingan mekanisme kerja;

2. mengoordinasikan wewenang dan tanggung jawab;

3. memberikan tanggung jawab pada personil sekolah hendaknya sesuai dengan sifat-sifat dan kemampuannya;

4. mengenal secara baik faktor-faktor psikologis manusia;

5. relativitas nilai-nilai. 


\section{JURNAL ILMIAH \\ BINA EDUKASI \\ ISSN 1979-8598 E-ISSN: 2655-8378 \\ http://journal.binadarma.ac.id/index.php/jurnalbinaedukasi \\ Vol. 14, No. 2, Desember 2021, 142 - 156}

\subsubsection{Manfaat Manajemen Pendidikan}

Bitar (2020), mengatakan bahwa manajer sekolah perlu memiliki pengetahuan yang memadai tentang manajemen pendidikan sebagai bekal kerja. Dengan kata lain, ia memiliki filsafat manajemen yang akan bermamfaat untuk:

1. pegangan dalam melaksanakan manajemen pendidikan;

2. melahirkan kepercayaan diri bagi kepala sekolah dalam proses manajemen guna mencapai tujuan sekolah;

3. memudahkan kepala sekolah dalam proses berpikir guna memecahkan permasalahan manajemen sekolah secara sistem;

4. memotivasi kepala sekolah untuk mendapatkan dukungan dari staf sekolah dan menarik partisipasinya;

5. selalu berpikir efektif dan efisien dalam mencapai tujuan;

6. mengetahui batasan-batasan wewenang dalam manajemen dan memimpin sekolah.

\subsection{Hakikat Tunagrahita}

\subsubsection{Konsep Tunagrahita}

Berikut adalah pengertian tunagrahita menurut para ahli:

1. Tunagrahita adalah suatu kondisi yang hadir pada saat lahir dan hal ini ditandai dengan fungsi intelektual signifikan di bawah rata-rata yaitu IQ 70 atau di bawahnya, (Halgin dan Whitebour, 2005 (dalam Bruno, dkk, 2012).

2. Raharja (2006), mengatakan bahwa "tunagrahita adalah kelainan yang ditandai dengan adanya keterbatasan yang signifikan dalam aspek fungsi intelektual dan prilaku adaptif yang diekspresikan dalam bentuk konseptual, sosial, dan keterampilan adaptif'.

3. Soemantri (2007), mengatakan bahwa tunagrahita merupakan kondisi dimana perkembangan kecerdasannya mengalami hambatan sehingga tidak mencapai tahap perkembangan yang optimal.

4. Wijaya (2013), mengatakan bahwa tunagrahita adalah individu yang memiliki intelegensi yang signifikan berada di bawah "rata-rata dan disertai dengan ketidakmampuan dalam adaptasi prilaku yang muncul dalam masa perkembangan".

Berdasarkan pendapat para ahli di atas dapat disimpulkan bahwa tunagrahita adalah kondisi keterbatasan intelektual yang berada di bawah rata-rata secara signifikan dan disertai dengan keterbatasan dalam dua bidang keterampilan adaptif atau lebih. 


\section{JURNAL ILMIAH \\ BINA EDUKASI \\ ISSN 1979-8598 E-ISSN: 2655-8378 \\ http://journal.binadarma.ac.id/index.php/jurnalbinaedukasi \\ Vol. 14, No. 2, Desember 2021, 142 - 156}

\subsubsection{Klasifikasi Anak Tunagrahita}

Klasifikasi anak tunagrahita pada umumnya dikelompokan berdasarkan intelegensi. Sesuai dengan definisinya bahwa anak tunagrahita merupakan anak yang memiliki intelegensi di bawah rata-rata. Seperti yang dikemukakan Robert Inngalls, 1987, Philip 1. Browing \& Rick Herber, 1974 (dalam Rochyadi dan Alimin, 2005).

Berdasarkan kemampuan kecerdasan, seseorang anak dikategorikan sebagai tunagrahita apabila kemampuan kecerdasannya menyimpang 2-3 standar deviasi dari kemampuan kecerdasana rata-rata. Jika kita menggunakan ukuran kemampuan kecerdasan dari StanfordBinet, dengan standar deviasi 16, maka anak yang memiliki IQ antara 68-54 ke bawah akan dikategorikan sebgai anak tunagrahita. Sementara itu jika kita menggunakan ukuran kemampuan kecerdasan berdasarkan David Wechsler dengan standar deviasi 15, maka anak yang memiliki IQ antara 69-56 ke bawah termasuk dalam kategori tunagrahita.

Berdasarkan standar deviasi tersebut menurut American Association on Mental Deficiency (AAMD), dalam Rochyadi dan Alimin (2005) mengatakan bahwa anak tunagrahita dapat diklasifikasikan menjadi empat kelompok sebagai berikut.

Individu yang memiliki IQ antara 2-3 standar deviasi di bawah rata-rata, dikategorikan sebagai anak tunagrahita ringan. Individu yang memiliki IQ antara 3-4 standar deviasi di bawah rata-rata, dikategorikan sebagai anak tunagrahita sedang. Individu yang memiliki IQ antara 4-6 standar deviasi di bawah rata-rata, dikategorikan sebagai anak tunagrahita berat, dan individu yang mempunyai IQ lebih dari 6 standar deviasi dikategorikan sebagai anak tunagrahita sangat berat". Penjelasan lebih rinci tentang klasifikasi anak tunagrahita berdasarkan skor IQ baik dari tes Stanford-Binet maupun dari David Wechsler.

Menurut Leo Kanner (Mumpuniarti, 2007) berdasarkan pandangan masyarakat:

a. Tunagrahita absolut (sedang) yaitu jelas nampak ketunagrahitaannya yang dipandang dari semualapisan masyarakat;

b. Tunagrahita Relatif (ringan) yaitu dalam masyarakat tertentu dipandang tunagrahita, tetapi ditempat yang lain tidak dipandang tunagrahita;

c. Tunagrahita Semu (debil) yaitu anak yang menunjukkan penempilan sebagai penyandang tunagrahita tetapi sesungguhnya mempunyai kemampuan normal. 
JURNAL ILMIAH

BINA EDUKASI

ISSN 1979-8598 E-ISSN: 2655-8378

http://journal.binadarma.ac.id/index.php/jurnalbinaedukasi

Vol. 14, No. 2, Desember 2021, 142 - 156

Tabel 1. Klasifikasi Anak Tunagrahita

\begin{tabular}{lll}
\hline \multicolumn{1}{c}{ Pendidikan } & \multicolumn{1}{c}{ Sosial } & \multicolumn{1}{c}{ Media } \\
\hline Mampu Didik & Ringan & Debil \\
(Educabel) & (mild morant) & \\
Mampu Latih & Sedang & Embical \\
(Friable) & (moderate) & \\
Perlu Rawat & Berat/ sangat berat & Idiot \\
\hline (Mumpuniarti, 2007) & &
\end{tabular}

Berdasarkan pendapat di atas, dapat ditegaskan bahwa klasifikasi anak tunagrahita, antara lain:

a. Anak tunagrahita (mampu didik) IQ 50/55 -70/75 (debil), yaitu dapatdididik dalam bidang akademik, mampu menyesuaikan sosial dalam lingkungan yang lebih luas, dapat mandiri, mampu melakukan pekerjaan sosial sederhana.

b. Anak tunagrahita sedang (mampu latih) IQ 20/25 - 50/55 (Embicil), yaitu dapat mengurus dirnya sendiri mampu melakukan pekerjaan yang perlu pengawasan di tempat terlindungi dapat berkomunikasi dan beradaptasi di lingkungan terdekat.

c. Anak tunagrahita berat (mampu rawat) IQ 0 - 20/25 (Idiot), yaitu sepanjang hidupnya tergantung pada bantuan yang perawatan orang lain.

\subsection{Penelitian Terdahulu}

Adapun penelitian yang relevan dengan penelitian ini sebagai berikut.

1. Daroni, Solihat dan Salim (2018) dengan judul "Manajemen Pendidikan Khusus di Sekolah Luar Biasa untuk Anak Autis". Dari hasil penelitian tersebut dapat diperoleh hasil bahwa pelaksanaan manajemen pendidikan khusus di Sekolah Luar Biasa Autis di Kabupaten Karanganyar dikoordinasi oleh seorang kepala sekolah. Dalam merencanakan program pendidikan, disesuaikan dengan kemampuan masing-masing siswa autis menggunakan IEP (Individual Educational Program). Sekolah memiliki susunan organisasi yang berkerja sesuai dengan tugasnya. Kepala sekolah bertugas mengkoordinasi manajemen sekolah, sedangkan guru bertanggungjawab melakukan manajemen di kelas.

2. Nopprima, Supardi dan Riswanti (2013) dengan judul "Manajemen Pembelajaran Anak Berkebutuhan Khusus (Studi Kasus Manajemen Pembelajaran Bahasa pada Anak Tunarungu di SLB PKK Provinsi Lampung)". Hasil yang diproleh dari penelitian tersebut menyatakan bahwa manajemen pembelajaran anak berkebutuhan khusus dalam hal ini pembelajaran bahasa anak tunarungu menyimpulkan (1) identifikasi dan asesmen telah dilakukan dengan baik terhadap siswa untuk mengetahui kemampuan dan 


\section{JURNAL ILMIAH \\ BINA EDUKASI \\ ISSN 1979-8598 E-ISSN: 2655-8378 \\ http://journal.binadarma.ac.id/index.php/jurnalbinaedukasi \\ Vol. 14, No. 2, Desember 2021, 142 - 156}

kebutuhannya; (2) proses manajemen pembelajaran bahasa pada anak tunarungu di SLB PKK Provinsi Lampung telah terlaksana dengan baik; (3) hasil dari proses manajemen pembelajaran bahasa adalah kemampuan komunikasi yang baik bagi siswa tunarungu.

3. Wati (2014) dengan judul "Manajemen Pendidikan Inklusi di Sekolah Dasar Negeri 32 Kota Banda Aceh”. Hasil yang diperoleh bahwa program kepala sekolah dalam menyukseskan pendidikan inklusi di SD Negeri 32 Kota Banda Aceh merupakan program yang sangat penting dan program tersebut didukung oleh semua staf di SD Negeri 32 Kota Banda Aceh. Program pendidikan inklusi ini diharapkan dapat memberikan kontribusi yang besar kepada anak berkebutuhan khusus dalam bidang pendidikan, sehingga tidak ditemukan kembali anak berkebutuhan khusus yang tidak sekolah. Berkenaan tentang Implementasi Program Pendidikan Inklusi di SD Negeri 32 Kota Banda Aceh, kepala sekolah telah mengupayakan pelaksanaan program yang telah disusun. Hal ini dapat diketahui melalui kegiatan perencanaan pembuatan program, pelaksanaan program, serta pengawasan program dilakukan oleh kepala sekolah dan wakil dari Dinas PPO Kota Banda Aceh. Pengawasan ini dilakukan untuk mengetahui sejauh mana program pendidikan inklusi ini berjalan di dalam kelas (kurikulum, sarana dan prasarana pembelajaran dan guru pendamping khusus), dan juga untuk memberikan penilaian baik yang telah tercapai maupun yang belum tercapai.

Berdasarkan beberapa hasil penelitian relevan terdahulu menunjukan bahwa berbeda dengan penelitian yang akan penulis lakukan yaitu "Penerapan Manajeman Pendidikan Khusus Anak Tunagrahita Sekolah Luar Biasa Negeri Ogan Ilir Sumatera Selatan".

\subsection{Metode Penelitian}

Penelitian ini bertujuan untuk menganalisis penerapan manajemen pendidikan khusus anak tunagrahita SLB Negeri Ogan Ilir Sumatera Selatan serta mengetahui faktor-faktor yang mendukung dan yang menghambat dari penerapan tersebut. Penelitian ini menggunakan metode deskriptif kualitatif. Pengumpulan data dilakukan dengan wawancara, observasi, dan dokumentasi. Teknik analisis data dilakukan melalui reduksi data, penyajian data, dan penarikan kesimpulan.

\section{HASIL DAN PEMBAHASAN}

Berikut adalah hasil penelitian dan pembahasan mengenai manajemen pendidikan Khusus Anak Tunagrahita Sekolah Luar Biasa Negeri Ogan Ilir Sumatera Selatan. 


\section{JURNAL ILMIAH \\ BINA EDUKASI \\ ISSN 1979-8598 E-ISSN: 2655-8378 \\ http://journal.binadarma.ac.id/index.php/jurnalbinaedukasi \\ Vol. 14, No. 2, Desember 2021, 142 - 156}

\subsection{Perencanaan Pendidikan}

Perencanaan merupakan sebuah aspek penting dalam pengelolaan pendidikan di sekolah, khususnya pada penerapan program sekolah. Kepala sekolah memegang peranan penting dalam aspek perencanaan, karena kepala sekolah merupakan penanggungjawab utama dalam sekolah.

Kepala SLB Negeri Ogan Ilir menjelaskan perihal perencanaan pendidikan di SLB Negeri Ogan Ilir dimulai dari Penerimaan Peserta Didik Baru (PPDB) untuk mengumpulkan dokumen atau administrasi sebagai syarat-syarat mendaftar sebagai siswa baru seperti akte kelahiran, fotocopy KK. Setelah semua dokumen sudah memenuhi syarat, lalu pihak sekolah melakukan analisis agar peserta didik yang mendaftar selain melengkapi persyaratan seperti yang telah dijelaskan sebelumnya, melampirkan juga hasil atau semacam surat keterangan dari pisikologmuntuk mengetahui kemampuan IQ peserta didik baru dan apakah dia termasuk debil besil dan idiot setelah sudah ada surat keterangan dari psikolog, sedangkan kalau untuk anak tunarungu itu harus ada dari Dokter THT untuk mengetahui seberapa jauh atau seberapa parah desibel pendengarannya tersebut. Setelah dilakukan serangkaian seleksi untuk PPDB, pihak sekolah dalam hal penempatan kelas juga melakukan assesment.

\subsection{Pengorganisasian}

Setelah melakukan manajemen perencanaan pendidikan, maka langkah selanjutnya adalah melakukan pengorganisasian. Kepala SLB Negeri Ogan Ilir menjelaskan bahwa terkait dengan tahap pengorganisasian yaitu anak yang sudah dinyatakan diterima di SLB Negeri Ogan Ilir, lalu masuk ke dalam kelas yang telah ditentukan oleh pihak sekolah sesuai dengan tingkat potensi anak masing-masing dan jenis kebutuhannya, hal ini dilakukan mengingat anak berkebutuhan khusus memiliki jenis yang berbeda sehingga pelayanan yang diberikan akan berbeda pula. Adapun jenis kelas yang ada di SLB Negeri Ogan Ilir ini terdiri dari:

1. Kelas Mampu Didik;

2. Kelas Mampu Latih dan;

3. Kelas Mampu Rawat

Selanjutnya, hasil wawancara yang dilakukan peneliti kepada salah seorang guru bernama Ibu Khodijah, S.Pd. selaku guru kelas X mengenai guru yang mengajar di kelas, dijelaskan bahwa dalam kelas hanya ada satu guru, hal ini dikarenakan dalam teorinya untuk satu kelas itu hanya ada peserta didik antara lima sampai dengan tujuh orang. Akan tetapi saat ini di SLB Ogan Ilir terkadang ada satu guru paling banyak membimbing sebanyak emapat sampai dengan lima orang peserta didik. Selain itu, untuk melakukan kegiatan belajar mengajar dalam hal 


\section{JURNAL ILMIAH \\ BINA EDUKASI \\ ISSN 1979-8598 E-ISSN: 2655-8378 \\ http://journal.binadarma.ac.id/index.php/jurnalbinaedukasi \\ Vol. 14, No. 2, Desember 2021, 142 - 156}

keterampilan, pada anak mampu latih terkadang dilaksanakan secara bersama-sama dengan guru-guru lain di ruang keterampilan. Sementara itu para guru yang mengajar di SLB Negeri Ogan Ilir tidak memiliki kualifikasi khusus, dalam arti kata bahwa untuk guru yang berkualifikasi sarjana pendidikan tidak menjadi dasar dalam mengajar akan tetapi tetap yang menjadi prioritas utama adalah sarjana pendidikan.

Pengorganisasian di sekolah dilakukan dalam menempatkan guru-guru di kelas-kelas tertentu. Semua pihak terlibat langsung dalam pengoranisasian, kepala sekolah berfungsi memberikan pengarahan dalam mengatur dan menempatkan guru-guru tersebut sesuai dengan karakteristik dan kemampuan masing-masing guru.

\subsection{Pelaksanaan}

Aspek-aspek yang ditekankan pada pelaksanaan pendidikan di SLB Ogan Ilir ini yaitu pada aspek pembiasaan, keteladanan, pembelajaran serta penguatan menciptakan lingkungan pendidikan terutama harus sesuai dengan Kurikulum Tahun 2013 atau K-13. Berdasarkan hasil wawancara dengan Kepala SLB Negeri Ogan Ilir, diperoleh pelaksanaan pendidikan diketahui bahwa setelah peserta didik ditempatkan pada kelas sesuai dengan pada assesment yang ditempatkan pada kelas sesuai dengan potensi dan kebutuhan masing-masing, lalu mereka masuk kelas untuk mengikuti program pembelajaran yang sama di kelas tersebut, selain melakukan pembelajaran bersama terkadang anak-anak juga diberikan program pelayanan secara pribadi atau individual yang disesuaikan dengan kebutuhan anak-anak, karena terkadang ada saja anak-anak yang perlu ditangani secara khusus. Lebih lanjut Kepala SLB Negeri Ogan Ilir mengatakan bahwa penerapan K13 sangat sulit dijangkau untuk anak-anak berkebutuhan khusus, oleh karena itu terkadang pihak sekolah berusaha menyesuaikan dengan kemampuan pada peserta didik, jika terlalu tinggi tingkat pemahamannya setidaknya ada diturunkan sedikit tingkat pemahamannya agar dapat dijangkau oleh peserta didik.

Penerapan manajemen pendidikan pada tahap pelaksanaan sangat bergantung pada dukungan keberhasilan yang diterapkan di sekolah tersebut. Seperti yang telah dijelaskan sebelumnya bahwa aspek-aspek yang diterapkan pada pelaksanaan pendidikan di SLB Negeri Ogan Ilir ini meliputi, pembiasaan, keteladanan, penguatan serta pembelajaran yang dilakukan di setiap kegiatan. Hasil wawancara yang dilakukan oleh peneliti kepada Ibu Khodijah, S.Pd. selaku guru kelas 2 SDLB menjelaskan bahwa guru-guru itu dituntut kemampuannya dalam menempuh pendidikannya untuk mengembangkan kira-kira kemampuan anak ini di mana begitu atau digali begitu sama saja dia membuat program seperti itu jadi program anak itu satu anak 1 program kalau untuk keterampilan, kalau untuk pengembangan terhadap nilai-nilai 


\section{JURNAL ILMIAH \\ BINA EDUKASI \\ ISSN 1979-8598 E-ISSN: 2655-8378 \\ http://journal.binadarma.ac.id/index.php/jurnalbinaedukasi \\ Vol. 14, No. 2, Desember 2021, 142 - 156}

Pancasila misalnya Ketuhanan Yang Maha Esa setiap kali hari Jumat itu kadang-kadang setelah senam, kami selalu duduk bersama untuk istilahnya itu semacam kultum itu sebentar, lalu keluar lagi.

Dari hasil wawancara di atas diperoleh bahwa setiap guru dituntut untuk membiasakan diri untuk mengembangkan program yang akan diberikan kepada peserta didik yang disesuikan dengan nilai-nilai Pancasila, seperti pada program Kuliah Tujuh Menit (Kultum) yang dilakukan setiap hari Jumat secara bersama-sama. Selanjutnya, berdasarkan hasil wawancara dengan Ibu Dharmawaty, S.Si., selaku guru kelas X SMLB mengatakan bahwa pembiasaan yang selalu dilakukan kepada peserta didik adalah mengucapkan salam. Mengucapkan salam dimulai dari anak-anak masuk dan keluar kelas ketika jam pelajaran berakhir. Namun terkadang juga mengucapkan salam dapat dilakukan ketika anak-anak bertemu secara tatap muka dengan guru, teman ataupun orang-orang yang berada di sekitar mereka. Selain mengucapkan salam, hal yang menjadi pembiasaan di SLB Negeri Ogan Ilir ini adalah selalu melakukan doa bersama ketika saat akan memulai pelajaran maupun saat mengakhiri pelajara.

Pada aspek pembelajaran, hal serupa juga dilakukan oleh para guru kepada peserta didik dengan menghubungkan RPP dengan nilai-nilai karakter seperti pada pelajaran pendidikan pancasila kewarganegaraan dengan memasukan nilai-nilai islami. Seperti pada sila pertama yaitu Ketuhanan Yang Maha Esa, anak-anak selalu diberikan contoh bagaimana cara menghargai perbedaan yang ada sebagai makhluk ciptaan tuhan. Selain itu, nilai-nilai islami juga memegang peranan yang penting pada aspek ini, seperti membaca surat Al Fatihah sebagai pembuka pelajaran dan surat An-nashr (Wal asri) ketika akan pulang. Menurut Kepala SLB Negeri Ogan Ilir, bahwa semenjak adanya pandemi covid-19, pelaksanaan pembelajaran dilakukan secara dalam jaringan atau online. Berdasarkan pengamatan yang dilakukan selama pembelajaran online ini, diperoleh bahwa pembelajaran yang dilakukan ini tidak begitu efektif, atau bisa dikatakan kurang berhasil, terlebih lagi dilakukan pada anak-anak yang berkebutuhan khusus. Lebih lanjut beliau mengatakan bahwa, pada saat pertemuan tatap muka di kelas saja banyak peserta didik yang kurang memahami terhadap materi yang disampaikan oleh guru, dan harus dilakukan dengan pendekatan individual, apa lagi jika pembelajaran tersebut dilakukan secara online.

Selain pembiasaan dan pembelajaran, peserta didik juga perlu diberikan contoh keteladanan yang baik dari para gurunya sebagai orang tua kedua peserta didik setelah orang tua di rumahnya. Keteladanan yang diberikan oleh para guru di SLB Negeri Ogan Ilir seperti selalu membantu teman jika teman sedang membutuhkan pertolongan dalam hal apa saja, membuang sampah pada tempatnya, serta mencuci tangan sebelum dan sesudah makan. 


\section{JURNAL ILMIAH \\ BINA EDUKASI \\ ISSN 1979-8598 E-ISSN: 2655-8378 \\ http://journal.binadarma.ac.id/index.php/jurnalbinaedukasi \\ Vol. 14, No. 2, Desember 2021, 142 - 156}

Berdasarkan wawancara kepada Ibu Ratih Purwasih, S. Pd., selaku guru kelas X SMALB mengatakan bahwa selain aspek pembiasaan, pembelajaran dan keteladanan, SLB Negeri Ogan Ilir juga selalu memberikan penguatan dalam bentuk penghargaan atau reward kepada peserta didik yang mampu membawa nama baik sekolah.

\subsection{Pengendalian}

Pengendalian adalah bagian terpenting dalam penerapan manajemen pendidikan di sekolah setelah perencanaan, pengorganisasian, dan juga pelaksanaan. Berdasarkan hasil wawancara yang diperoleh dari Kepala SLB Negeri Ogan Ilir, dijelaskan bahwa dalam melakukan penerapan semua unsur-unsur yang ada dalam manajemen pendidikan di sekolah, bukan hanya pihak sekolah, seperti kepala sekolah, guru dan juga peserta didik yang berperan serta, melainkan juga peran orang tua sangat membantu sekali guna keberhasilan putra/putrinya menimba ilmu. Guru dan orang tua harus selalu sersinergi terhadap program-program yang dilakuakn di sekolah. Sementara itu, orang tua juga dapat memberikan masukan kepada sekolah jika ada informasi-informasi yang berhubungan dengan sekolah, mengingat di SLB Negeri Ogan Ilir adalah sekolah milik pemerintah yang di dalamnya ada sebuah wadah atau perkumpulan para orang tua/wali murid dari peserta didik yang dinamakan "Komite Sekolah"

Kepala sekolah memiliki peranan penting dalam proses pengelolaan sekolah, hal ini dikarenakan bahwa kepala sekolah adalah sebagai pemimpin tertinggi yang sangat berpengarauh terhadap kemajuan sekolah

\section{SIMPULAN}

Berdasarkan hasil penelitian pada analisis kasus dan pembahasan kasus tentang penerapan manajemen pendidikan khusus anak tunagrahita di SLB Negeri Ogan Ilir yang telah peneliti paparkan sebelumnya, maka dapat disimpulkan bahwa keberhasilan manajemen pendidikan yang diterapkan pada anak berkebutuhan khusus yaitu anak tunagrahita tidak terlepas dari adanya proses pengelolaan yang baik yang dilakukan dari pihak sekolah yang dimulai dari proses perencanaan, proses pengorganisasian, proses pelaksanaan, serta proses pengendalian. Dalam merencanakan program pendidikan, disesuaikan dengan kemampuan masing-masing siswa. Sekolah memiliki susunan organisasi yang berkerja sesuai dengan tugasnya. Kepala sekolah bertugas mengkoordinasi manajemen sekolah, sedangkan guru bertanggungjawab melakukan manajemen di kelas. Selain pengelolaan yang baik dalam menerapkan manajemen pendidikan, dukungan dari semua elemen sumber daya manusia yang terlibat seperti sekolah yang di dalamnya terdapat kepala sekolah, dewan guru, dan pihak-pihak 


\section{JURNAL ILMIAH}

BINA EDUKASI

ISSN 1979-8598 E-ISSN: 2655-8378

http://journal.binadarma.ac.id/index.php/jurnalbinaedukasi

Vol. 14, No. 2, Desember 2021, 142 - 156

sekolah lainnya. Selain dukungan dari pihak sekolah, dukungan dari orang tua, keluarga, serta lingkungan masyarakat lainnya sangat menentukan keberhasilan tersebut.

\section{DAFTAR PUSTAKA}

Achmad, Munib. (2004). Pengantar Ilmu Pendidikan. Semarang: UPT UNNES PRESS.

Agus, Taufik, dkk. (2011). Pendidikan Anak di SD. Jakarta: Universitas Terbuka.

Arikunto, Suharsimi. (2006). Prosedur Penelitian : Suatu Pendekatan Praktik, Edisi Revisi VI. Jakarta : PT Rineka Cipta.

Arikunto, Suharsimi. (2008). Manajemen Pendidikan. Yogyakarta: Aditya Media F. Ilmu Pendidikan UNY.

Bitar. (2020). Manajemen Pendidikan - Pengertian, Tujuan, Fungsi, Prinsip, Manfaat, Ruang Lingkup, Para Ahli. https://www.gurupendidikan.co.id/manajemen-pendidikan/. Diunduh 10 november 2020.

Bruno, dkk. (2012). Classroom Management of Mental Retardation. Department of Educational Psychology. Guidance and Counselling Faculty of Education. University of Port Harcourt . Nigeria: International Journal

Daroni, Ali, Gangsar, Gina Solihat dan Abdul Salim. (2018). Manajemen Pendidikan Khusus di Sekolah Luar Biasa Untuk Anak Autis. https://ejournal.uksw.edu/kelola/article/view/1890. Diunduh 10 November 2020.

di Sekolah Dasar. Kelola Jurnal Manajemen Pendidikan, 4(1), 59-71.

Hamalik, Oemar. (2007). Manajemen Pengembangan Kurikulum. Bandung: PT. Remaja Rosda Karya.

Mailani, E.(2018). Upaya Meningkatkan Hasil Belajar Matematika pada Materi Pecahan melalui Permainan Monopoli Pecahan. Jurnal Handayani PGSD FIP UNIMED, 4(1), 114.

Mantja, W. (2016). Manajemen Pendidikan dalam Era Reformasi. Jurnal Ilmu Pendidikan, 7(2), 87-96.

Maria, E \& Sediyono, E. (2017). Pengembangan Model Manajemen Pembelajaran Berbasis TIK.

Muhadjir, Noeng. (1996). Metodologi Penelitian Kualitatif. Edisi Ke-3. Rake Sarasin: Yogyakarta.

Mumpuniarti. (2007). Pembelajaran Akademik Bagi Tunagrahita. Yogyakarta: FIP UNY.

Noordyana, M. A. (2016). Meningkatkan Kemampuan Berpikir Kritis Matematis Siswa melalui Pendekatan Metacognitive Instruction. Jurnal Pendidikan Matematika 


\section{JURNAL ILMIAH}

BINA EDUKASI

ISSN 1979-8598 E-ISSN: 2655-8378

http://journal.binadarma.ac.id/index.php/jurnalbinaedukasi

Vol. 14, No. 2, Desember 2021, 142 - 156

Nopprima, Arie Laili, Sumadi Sumadi, Riswanti Rini.(2013). Manajemen Pembelajaran Anak Berkebutuhan Khusus. Http://Jurnal.Fkip.Unila.Ac.Id/Index.Php/Jmmp/Article/View/3978, Diunduh 11 November 2020.

Poerwandari, E. K. (2005). Pendekatan kualitatif untuk penelitian perilaku manusia (edisi.Ketiga). Depok: LPSP3 Fakultas Psikologi Universitas Indonesia.

Raharja, D. (2006). Pengantar Pendidikan Luar Biasa. University of Tsukuba.

Rochyadi, E. dan Alimin, Z. (2005). Pengembangan Program Pembelajaran Individual Bagi Tunagrahita. Jakarta: Departemen Pendidikan Nasional.

Somantri. (2007). Psikologi Anak Luar Biasa. Bandung: PT Refika Aditama. STKIP Garut, 5(2), 120-127.

Sugiyono. 2010. Metode Penelitian Pendidikan Pendekatan Kuantitatif, kualitatif, dan R\&D. Bandung: Alfabeta.

Wati, Ery. (2014). Manajemen Pendidikan Inklusi Di Sekolah Dasar Negeri 32 Kota Banda Aceh. https://jurnal.ar-raniry.ac.id/index.php/didaktika/article/view/508. Diunduh 11 November 2020.

Widodo, A., Waridin, \& Maria, K. J. 2011. Analisis Pengaruh Pengeluaran Pemerintah di Sektor Pendidikan dan Kesehatan terhadap Pengentasan Kemiskinan melalui Peningkatan Pembangunan Manusia di Provinsi Jawa Tengah. Jurnal Dinamika Ekonomi Pembangunan, 1(1), 25-42.

Wijaya, A. (2013). Teknik Mengajar Anak Tunagrahita (Disabilitas Inteligensi Gangguan Intelegtual). Yogyakarta: Imperium

Yusnita, Mira. (2016). Rumusan Program Pembelajaran Keterampilan Merawat Diri bagi Anak Tunagrahita Sedang di SLB X Palembang. Universitas Pendidikan Indonesia repository.upi.edu.perpustakaan.upi.edu. Diunduh 9 November 2020. 